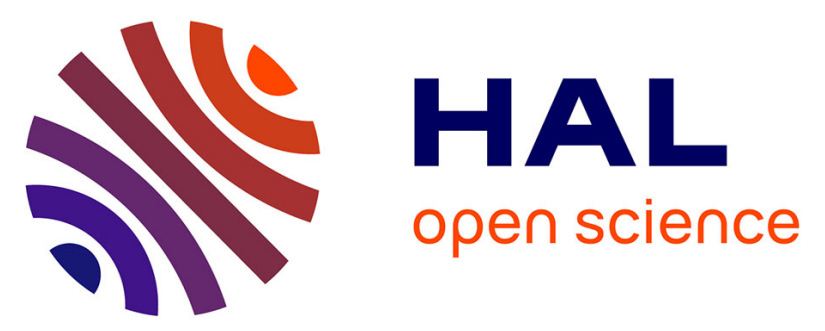

\title{
Characterization of circulating tumor cells as a reflection of the tumor heterogeneity: myth or reality?
}

Hannah K Brown, Marta Tellez-Gabriel, Pierre-François Cartron, François M Vallette, Marie-Françoise Heymann, Dominique Heymann

\section{To cite this version:}

Hannah K Brown, Marta Tellez-Gabriel, Pierre-François Cartron, François M Vallette, MarieFrançoise Heymann, et al.. Characterization of circulating tumor cells as a reflection of the tumor heterogeneity: myth or reality?. Drug Discovery Today Biosilico, 2018, Epub ahead of print. 10.1016/j.drudis.2018.11.017 . inserm-01947472

HAL Id: inserm-01947472

https://www.hal.inserm.fr/inserm-01947472

Submitted on 6 Dec 2018

HAL is a multi-disciplinary open access archive for the deposit and dissemination of scientific research documents, whether they are published or not. The documents may come from teaching and research institutions in France or abroad, or from public or private research centers.
L'archive ouverte pluridisciplinaire HAL, est destinée au dépôt et à la diffusion de documents scientifiques de niveau recherche, publiés ou non, émanant des établissements d'enseignement et de recherche français ou étrangers, des laboratoires publics ou privés. 


\title{
Characterization of circulating tumor cells as a reflection of the tumor heterogeneity: myth or reality?
}

\author{
Hannah Brown K. ${ }^{1}$, Marta Tellez-Gabriel ${ }^{2}$, Pierre-François Cartron ${ }^{3}$ \\ François Vallette ${ }^{3}$, Marie-Francoise Heymann ${ }^{3}$, Dominique Heymann ${ }^{1,3}{ }^{*}$
}

${ }^{1}$ INSERM, European Associated Laboratory "Sarcoma Research Unit", Department of Oncology and metabolism, Medical School, University of Sheffield, United Kingdom.

${ }^{2}$ RNA and molecular pathology (RAMP) research group. Department of Medical Biology. The Artic University of Norway (Tromso), Norway.

${ }^{3}$ INSERM, Institut de Cancérologie de l'Ouest, LabCT, U1232, CRCINA, Université de Nantes, Université d'Angers, 44805 cedex, Saint Herblain, France.

\section{*Corresponding author}

Prof. D. Heymann

Institut de Cancérologie de l'Ouest, INSERM, LabCT, Blvd Jacques Monod, 44805 Saint-Herblain, France

Tem.: +33 (0) 240679 841; Email: dominique.heymann@univ-nantes

Keywords: circulating tumor cells; microfluidics; tumor heterogeneity; monitoring; clinical trials

Teaser: Circulating tumor cells are spatially and temporally heterogeneous, they reflect tumor progression and are an invaluable tool for therapeutic decisions. 


\begin{abstract}
Oncology has entered in the era of personalized medicine with its advantages such as limited invasiveness during sample collection, robustness, precision and speed. This new era has led to novel practices of tissue sampling (e.g. needle biopsy) and the main goal of diagnostic medicine is now to detect crucial events in "infinitely" small samples. The key question is now to determine if the rare cell events isolated and characterized from these samples are reliably reflecting the initial and/or metastatic disease and particularly the heterogeneity of the tumor. The present review will give a short overview of the most recent methods developed for the isolation and characterization of rare cell events in clinical practice with a specific focus on circulating tumor cells. We will discuss the biological value to study these cells at the single cell level and how these rare cell events can reflect tumor heterogeneity. The potential biomedical applications (disease modeling, drug screening, therapeutic decision, monitoring, etc.) will be critically discussed in light of precision medicine.
\end{abstract}




\section{Introduction}

Cellular, genetic and molecular heterogeneity is a hallmark of cancer. When a patient is first diagnosed, the tumor mass is composed of a couple of thousand to several million cells, including cancer cells functionally linked to non-cancer cells in the microenvironment (e.g. endothelial cells, immune cells). This heterogeneity, which has been documented for several decades, initially for morphological and diagnostic assessment, is observed not only spatially in distinct tumor areas, but also at the cell level [1]. Darwin's theory of evolution provides some explanations for this diversity. Cancer evolves in application of Darwinian principles, associating clonal proliferation, genetic instability with random mutational changes, and epigenetic modifications within the clonal population resulting in genetic diversity (Figure 1). Sir James Paget added to these principles by the "seed and soil" theory, describing that the combination of multiple genetic events and a favorable microenvironment is required to maintain "cancer stem-like cells" and drive tumor initiation and growth [2]. Consequently, heterogeneity and cancer development is controlled by the cellular and molecular neighborhood, called the tumor microenvironment, which fuels selection pressure on cancer cells by modulating oxygen levels, and supplying nutriments and growth factors. Cancer is now viewed as a complex, dynamic ecosystem where the evolution within a tumor is driven by selection through the microenvironment [3-6]. Tumors can contain pre-existing resistant clones that evolve and survive genetically thanks to selective pressure, these cells are furthermore thought to be the 'seeds' responsible for repopulation of the primary tumor and of distant organs $[7,8]$. Nevertheless, intra-tumor heterogeneity cannot be limited solely to genetic events. Numerous studies, carried out on cell lines considered to have a high degree of genetic homogeneity, have shown that drug responses are also strongly 
associated with intercellular epigenetic heterogeneity [9]. Epigenetic mechanisms are defined by numerous processes, including DNA methylation, post-translational modifications of histones and chromatin remodeling, which are essential for genome organization, gene expression, and cell function [10]. The failure of cancer therapies to achieve durable therapeutic responses is often attributed to intra-tumor heterogeneity. Consequently, better characterization of intra-tumor heterogeneity would provide a powerful opportunity to track back through the formation of the malignancy and define in detail the evolution of the tumor, from the tumor-initiating events to the subsequent development of malignant clones.

The most recent surgical methods of diagnostic sampling used, such as needle biopsies, limit the amount of material available for biological analyses. In addition, a biopsy is a partial snapshot of the tumor mass at a given time and does not allow longitudinal studies. Consequently, a source of biological materials representative of the disease in real time, more accessible with low invasive methods for repeated sampling is mandatory to monitor the clonal evolution of cancer cells during treatments. Distant metastases are unfortunately the common consequence of most cancer types and cancer cells predominantly spread through the blood vasculature or can be also associated with spread from the lymphatic system into the blood vasculature [11,12]. After a series of consecutive and very selective events (e.g. intravasation, survival in the circulation, arrest in distant capillaries; extravasation, instalment of migrant cells in the distant organ), only a small number of cancer cells will successfully survive all steps of the metastatic cascade. Although the metastatic process can overall be considered as a relatively inefficient process, its high selectivity contributes to tumor heterogeneity and thus drug resistance. Circulating 
tumour cells (CTCs) that have migrated into the bloodstream have originated from established tumor masses (e.g. primary or metastatic sites) [13-16]. Based on their location CTCs are easily accessible; however, the extremely low number generates major challenges for their isolation thus requiring specific technological approaches.

\section{Technical approaches for isolating CTCs}

CTCs are cell events travelling alone and/or in clusters among abundant leukocytes, thrombocytes and erythrocytes [17-19]. CTC clusters are rare compared to single CTCs but Aceto et al. demonstrated a high metastatic potential, around 23- to 50-fold increased in comparison to single cells [17]. More recently, by using microfluidic and zebrafish approaches, Au et al. demonstrated that CTC clusters rapidly and reversibly reorganize into single-file chain-like geometries, reducing their thermodynamic resistance and allowing CTC clusters to pass through capillary-sized constrictions [18]. They hypothesized that circulating tumor "microemboli" by CTC clusters may be an important process of tumor dissemination. Furthermore, CTC clusters are considered as hybrid epithelial-mesenchymal transition cell agglomerates with higher metastatic potential [19]. Based on their rarity ( 1 to 10 cells per $\mathrm{mL}$ of blood), analysis of CTCs requires reliable approaches with high efficiency and specificity. The number of technical tools for the isolation of CTCs has exploded in the last decade [20-24]. A non-exhaustive list of the most recent methods is presented in Figure 2, they can be used separately or in combination depending on the objectives. Some of them can be used as a pre-enrichment step and include a wide range of techniques based on the different properties of CTCs allowing the separation of cancer cells from hematopoietic cells (e.g. negative magnetic bead selection). Others 
are more adapted for single cell isolation [e.g. DEPArray ${ }^{\circledR}$ ]. Three types of CTC specificities are conventionally used for their isolation: i) biological characteristics (e.g. cell surface markers); ii) physical properties of cancer cells including bigger size, lowest deformability, altered density and electric charges; iii) functionalities.

\section{Isolation by density gradient}

CTCs like most cancer cells exhibit abnormal cytological features including a larger size and heterogenous nuclear shape leading to differential biomechanical and electric properties compared to healthy cells. These modified physical characteristics are at the origin of the methods used for their isolation. Their higher nuclear to cytoplasm ratio allows their isolation by density gradient centrifugation [e.g. Ficoll-HyPaque, Percoll, OncoQuick ${ }^{\circledR}$ (Greneir Bio-One international, Courtaboeuf, France)] based on differences in their sedimentation coefficients (Figure 2). Gertler et al. have compared the density gradient centrifugation system OncoQuick ${ }^{\circledR}$ with the standard density gradient Ficoll-HyPaque and showed that both methods led to similar cancer cell recovery rates (range $70 \%$ to $90 \%$ ) [25]. However, if such approaches are efficient to enrich biological samples in CTCs and are relatively inexpensive, the recovery of CTC clusters and large CTCs is not efficient and the purity of collected CTCs is low with the presence of numerous leukocytes. In addition, the cytotoxicity of density medium can impact on cell viability. Density gradient centrifugation should be considered as pre-enrichment method and should be combined with another CTC isolation approach. 


\section{Isolation by microfiltration}

The cytological characteristics of CTCs have led to the development of microfiltration devices in order to capture these rare cell events $[23,26]$. Microfiltration is a simple process allowing the enrichment of large volumes of blood in minutes with a high recovery rate ( $>85 \%$ depending on the device used) and is independent of any biomarkers expressed by CTCs. Small format devices dedicated to targeted downstream analyses have been developed (ScreenCell, Sarcelles, France; ISET, RareCells, France). ScreenCell devices cover three main filtration systems: i) ScreenCell ${ }^{\circledR}$ Cyto requires fixed cells and is dedicated to molecular techniques; ScreenCell ${ }^{\circledR}$ CC allows CTCs recovery for cell culture and iii) ScreenCell ${ }^{\circledR}$ MB is adapted for RNA or DNA analyses [27,28]. However, the final purity of CTCs collected is relatively low $(\sim 10 \%)$, single CTCs and CTC clusters are simultaneously captured and depending to the flow and pressure used, cells can be damaged. Furthermore, the detachment of captured CTCs on the filtration membrane can be difficult thus limiting the downstream analyses. Furthermore, the background signal on the filters after immunocytochemistry used for the detection of CTCs can restrict their use.

\section{Isolation by microfluidic devices}

Several microfluidic devices designed to isolate CTCs have been developed [ApoStream $^{\circledR}$ (ApoCell, Houston, TX, USA); ClearCell ${ }^{\circledR}$ FX (Clearbridge Biomedics, Singapore); CTC-iChip technology (D.A. Harber, Massachusetts General Hospital Cancer Center; M. Toner, Harvard Medical School; Boston, MA); DEPArray ${ }^{\circledR}$ (Silicon Biosystem, Menarini, Bologna, Italy); Parsortix ${ }^{\circledR}$ (Angle, Surrey, UK)]. A variety of microchips have been developed to fractionate cells in blood according to 
their size, deformability/elasticity, surface electric charges and/or expression of biomarkers. Such approaches are relatively expensive and require the use of specific cassettes/cartridges, however, their main advantages are their high sensitivity and high efficiency. Some devices have the capacity to process or even require low volumes of blood/fluids explaining the necessity of pre-enrichment methods for reducing the initial sample in case of large volumes. In addition, these systems provide researchers with the opportunity to isolate single cells. CTC isolation based on microfluidic systems often involves a pre-enrichement step and an isolation/capture step. For example, the Parsortix ${ }^{\circledR}$ device enriches CTCs in blood (from $10 \mathrm{~mL}$ to $\sim 200 \mu \mathrm{L}$ ) based on their differential size and deformability. A microfluidic cassette is used in which CTCs with contaminating leukocytes can be immunostained and recovered [29]. Pools of CTCs captured by Parsortix ${ }^{\circledR}$ can be processed by DEPArray ${ }^{\circledR}$ or ApoStream ${ }^{\circledR}$ systems for isolation of single and pure CTCs. These systems work based on the differential electric charge of the cells and have a reported recovery efficiency of over $70 \%$ combined with excellent cell viability (97\%) [30]. The DEPArray ${ }^{\circledR}$ technology provides in addition to the DEP field flow fractionation, an image-based cell selection allowing the isolation of pure, single cell CTCs (stained for selected biomarkers) and an evaluation of cell-DNA content by DAPI staining ("DNA index") [30-32]. CTC-iChip technology combines size-based exclusion of erythrocytes and thrombocytes, immunomagnetic depletion of leukocytes and CTCs positioning in microchannels. More recently, $\mathrm{Wu}$ et al developed a system combining microfluidics and acoustics for the isolation of CTCs [33]. High-throughput accoustic separation has a reported recovery rate of more than $85 \%$ and allows the determination of size distribution, phenotypic investigation and post-separation cell culture. Overall, microfluidics are characterized by an excellent 
purity of recovery $(>80 \%)$ with limited disturbances of the CTCs and allow the isolation of pure single CTCs or/and clusters from small volumes. However, they are relatively expensive (e.g. device, consumable) and are time consuming techniques.

\section{Isolation by immunoaffinity}

Immunoaffinity-based CTC isolation (negative or positive selection) one of the oldest methods used for isolating pure cell populations. The systems $\left[\operatorname{EasySep}^{\circledR}\right.$ or RosetteSep $^{\circledR}$ (CELL Tech, Cambridge, United Kingdom), MojoSort ${ }^{\circledR}$ (Biolegend, San Diego, CA, USA), Dynabeads ${ }^{\circledR}$ (ThermoFisher, Waltham, Massachusetts, USA), IsoFLux $^{\circledR}$ (Fluxion Biosciences, Alameda, CA, USA), AdnaTest ${ }^{\circledR}$ (Qiagen, Germany)] are based on the biological properties of CTCs that express cytoplasmic and/or membrane biomarkers (e.g. EpCAM). Some of them have been improved by adding an activated filter to capture and retain labeled cells [MACS ${ }^{\circledR}$ (Miltenyi Biotec GmbH, Bergisch Gladbach, Germany) and MagniSort ${ }^{\circledR}$ (eBioscience, San Diego, CA)] or by adding a robotic arm with a magnetic rod that binds labeled cells [MagSweeper ${ }^{\circledR}$ (Jeffrey's Laboratory, Stanford, CA, USA)]. Their main advantages are their high efficiency, high cell viability and high purity, however, immunomagnetic isolation is dependent on markers expressed by CTCs, the specificity of the targeted antigen and do not allow the isolation of pure single cells. The CellSearch ${ }^{\circledR}$ device combines antibody affinity for selecting CTCs and an imagebased cell selection system [34]. CellSearch ${ }^{\circledR}$ is currently the exclusively US-FDA approved device for CTC detection in metastatic breast, prostate and colorectal cancer. Several devices combine microfluidic and immunoaffinity isolation through microchannels coated with antibodies against specific targeted antigens expressed by CTCs [OnQChip ${ }^{\circledR}$ (On-Q-ity Inc., Whatham, MA, USA); OncoCEETM chip (Biocept 
Laboratories, San Diego, CA)]. Gilupi CellCollector ${ }^{\circledR}$ (Postdam, Germany) has been developed for in vivo CTC isolation and is CE approved. This cell collector is a medical stainless steel wire coated with anti-EpCAM antibody (length: $16 \mathrm{~cm}$; diameter: $0.5 \mathrm{~mm}$ ) implanted intravenously for 30 minutes in order to come into contact with a large volume of blood containing CTCs. In more than 2,000 patients, the detection rate is around $70 \%$ in early/late cancer stages. Its implantation for a duration of 30 minutes increases the chances of isolating CTCs but this device is currently restricted to EpCAM-expressing cells. Whatever the system used, all of them are limited by the expression of a membranous marker of interest expressed by CTCs.

\section{Functional assessment of CTCs}

To overcome some of the limitations mentioned above, functional assessment of CTCs can be performed. In addition to the commonly used Chick chorioallantoid membrane assay (CAM), two recent approaches have been proposed to identify and characterize CTCs: TelomeScan ${ }^{\circledR}$ (Oncolys Biopharma, Tokyo, Japan) and EPISPOT. TelomeSCan ${ }^{\circledR}$ is a genetically engineered adenovirus type 5 with a human Telomerase Reverse Transcriptase (hTERT) gene promoter sequence in the upstream region of the viral E1 gene which is responsible for replication of the adenovirus. Viral replication can therefore only take place in cells with active telomerase activity such as cancer cells. In the E3 region of the vector is a Green Fluorescent Protein (GFP) gene under the control of the cytomegalovirus promoter allowing visual detection of cancer cells containing replicating virus. EPISOPT is an ELISPOT assay dedicated to the detection of proteins secreted from epithelial cancer cells [35]. Isolated CTCs are cultured for a short time on a membrane coated with antibodies that 
capture the corresponding secreted proteins which are subsequently detected by secondary antibodies labelled with fluorochromes. EPISPOT therefore allows the detection and characterization of CTCs on the basis of their secretome.

\section{CTCs constitute a heterogeneous cell population}

CTCs spread from a solid tumor mass and reach distant organs through the bloodstream. Intravasation and extravasation require complex cell modifications to facilitate the motility of cancer cells that involves the Epithelial-to-Mesenchymal Transition (EMT). EMT results in numerous cell rearrangements including loss of cellular contact junctions, cell adhesion and cell polarity and induces marked modifications of epithelial cell morphology corresponding to a modified differentiation profile [36]. CTCs undergo an inverted process (MET) when they settle in the metastatic foci. EMT leads to a loss of epithelial makers for carcinoma cells (e.g. EpCAM) and expression of mesenchymal makers (e.g. vimentin). Similar mechanisms have been described for sarcoma cells. In addition to the genetic instability and mutations described in the introduction, EMT strongly contributes to the heterogeneity of cancer cells. For instance, inoculation of $\mathrm{EpCAM}^{+}$breast cancer cells in mice leads to the detection of a mixture of $\mathrm{EpCAM}^{+}$and $\mathrm{EpCAM}^{-} \mathrm{CTC}$ in the blood after three weeks and similarly an injection of EpCAM cells results in the detection of both $\mathrm{EpCAM}^{+}$and $\mathrm{EpCAM}^{-} \mathrm{CTCs}$ [23]. In 19 patients with $\mathrm{ER}^{+} / \mathrm{HER}^{-}$ primary tumors, $84 \%$ acquired HER $2^{+}$CTCs illustrating the high plasticity of cancer cells to develop drug resistance and the relative value of membranous biomarkers [37]. Lots of studies have demonstrated the value of CTC quantification as a prognosis factor in metastatic as well as in metastatic patients [21,38]. However, recent studies underlined the high cellular heterogeneity within CTCs in breast [39- 
43], prostate [44-47], hepatocellular carcinoma [48], colorectal [49,50] and lung cancer [51]. Gasch et al. observed in a series of 290 metastatic breast cancer patients the presence of CTCs in $61.7 \%$ and showed a high heterogeneity concerning PI3K mutations and Her2 expression by CTCs [43]. Similarly, in a short series of inflammatory breast cancer patients, Bingham et al. confirmed the presence of very high-frequency mutations (69\% TP53, 16\% RB, 13\% PI3KCA, ErbB2 2\%) in CTCs matching tissue biopsies [41]. Interestingly, they found a high heterogeneity of CTCs as revealed by the isolation of various clones harboring different combinations of mutated and wild-type genes. Similar heterogeneity has been described by Scher et al. in prostate cancer patients [44]. Their study showed that lower heterogeneity scores were associated with a longer median survival of patients treated with androgen receptor signaling inhibitors and higher heterogeneity of CTCs with shorter median survival of patients treated with taxanes. An interesting notion of spatial heterogeneity of CTCs has been suggested by Sun et al. in a series of 73 patients suffering from hepatocellular carcinoma [48]. These authors analyzed CTCs isolated from blood collected in the peripheral vein, peripheral artery, hepatic veins, infrahepatic inferior vena cava, and portal vein before tumor resection. Single-cell characterization demonstrated that EMT status of CTCs was heterogeneous across the vascular compartments and suggested that CTC heterogeneity can influence postoperative lung metastasis and intrahepatic recurrence. In colorectal cancer, using the CellSearch ${ }^{\circledR}$ device, Kondo et al. revealed the heterogeneity in KRAS status among CTCs [49] and Meassritakis et al. described the phenotypic heterogeneity of CTCs in patients with small cell lung cancer on the basis of TTF-1, CD56 and EpCAM expression [51]. CTC heterogeneity is now recognized by the scientific community strengthening the need to establish a full genomic and molecular profile of CTCs at the single-cell level. 


\section{Do CTCs reflect the genetic/molecular patterns of the primary tumors? The biologic value of CTCs}

More than 200 clinical trials focused on CTCs are registered in the NIH database (clinical trial.gov) and 79 are currently recruiting (Table 1) illustrating the extraordinary enthusiasm for the biology of CTCs and their potential biological/clinical value [21]. CTC count correlates in most studies with disease progression. Thus, in a very recent meta-analysis including 21 studies, Bidard et al. investigated the clinical value of CTCs in non-metastatic breast cancer patients treated by neoadjuvant chemotherapy [38]. Data of patients, in particular information on CTCs collected by CellSearch ${ }^{\circledR}$, were gathered before neoadjuvant chemotherapy $(n=1574)$ and before surgery $(n=1200)$. From 861 patients included with full data available, the authors demonstrated that CTC count was an independent and quantitative prognostic factor in early breast cancer patients treated by neoadjuvant chemotherapy. However, it has also been demonstrated that the CTC phenotype (e.g. mi-RNA profile) does not always correlate with CTC count due to their high heterogeneity and that it could be modulated during the course of treatment [50]. Is it therefore necessary to determine if CTCs could reflect the primary tumor or metastatic foci and how CTCs are modulated during treatments? Paoletti et al. carried out next generation sequencing (NGS) of somatic mutations and copy number alterations of CTCs from metastatic breast cancer [51]. From 12 patients, they found $85 \%$ concordance in at least one more somatic mutation and copy number alteration between paired CTCs and metastatic tissue. These authors also identified the presence of a minority CTC subclone harboring a novel active mutation (ESR1 pA569S). De 
Luca et al. performed NGS of CTCs from 4 patients with metastatic breast cancers and found a discordance between the mutational status of the primary tumor and CTCs observed in 3 patients [52] reinforcing the data obtained by Jabokova et al. in which HER2, and ESR status of CTCs differs from the status of primary tumors [40]. Similarly, prostate cancer, Jiang et al. showed that \% of the clonal mutations and intra/interchromosomal rearrangements identified in CTCs could be found in the primary or metastatic tumors [53]. Carlsson et al. compared bone marrow aspirates and blood CTCs in 14 prostate cancer patients and observed that the proportions of androgen receptor negative and positive cells were similar between compartments, however, whole genome copy number profiling in single cells from 3 patients identified distinct clonal patterns between both bone marrow and blood [54]. The reports from colorectal and lung cancer show similar results. Lyberopoulou et al. observed in 52 colorectal cancer patients a discordance between primary tumor and CTCs for KRAS, BRAF, CD133, re3130 and Plastin-3 rs6643869 [55]. This discordance has been confirmed by Kondo et al. [49] and in recent meta-analysis including 9 studies and 244 patients [56]. Similar discordance was observed at the epigenetic level [50]. In lung cancer, Guibert et al. showed a more frequent PD-L1 expression (83\%) in CTCs than in tumor tissue (41\%) [57]. In this study, high CTC number and pre-treatment were associated with increased risk of death and progression. The authors concluded that PD-L1+ CTCs detected before treatment were associated with bad prognosis in patients treated with PD-1 inhibitors. If the spatial heterogeneity of CTCs has been suggested [48], a dynamic/temporal heterogeneity has also been proposed $[58,59]$. By using murine pre-clinical model of prostate cancer, Kermanshah et al. monitored the phenotype changes of CTCs during treatment and gave evidence that CTCs of metastatic mice displayed dynamic and 
heterogeneous profiles compared to mice with local disease [58]. Interestingly, CTC heterogeneity decreased after chemotherapy and was followed by a significant reduction of metastasis incidence. Overall, these data revealed the partial genomic overlap of CTCs and primary/metastatic tumor foci at a defined time, however, the clonal architecture of advanced disease is a dynamic process, with establishment of new clones gaining dominance in response to treatment.

\section{Conclusions}

CTCs should be considered as a picture of the tumor tissue at a given time. Indeed, recent studies support the cellular heterogeneity within CTCs that partly reflects the spectrum of mutations in the primary and metastatic tumors. CTC profile evolves as the disease progresses and in addition to the mutations detected in tumor tissues, CTCs harbor new sets of mutations reflecting the emergence of minority sub-clones and/or the evolution of pre-existing clones under the drug pressure. In addition to this temporal evolution fueling CTC heterogeneity, spatial heterogeneity contributes to amplify the process in a dynamic manner. CTCs are rare cell events frequently masked by the background of peripheral leukocytes, and in such context molecular characterization of CTCs in the blood remains challenging. Expansion of patientderived CTCs as 3D organoids or in specific microfluid culture devices may be an option to get enough biological material for molecular pehnotyping or/and drug screening [60]. Liquid biopsies also include circulating tumor DNA (ctDNA) which is mainly released after tumor cell death. Although ctDNA can allow the assessment for the emergence of specific cancer cell sub-clones characterized by a specific new set of mutations, ctDNA cannot give a full picture of tumor evolution combining dynamic genetic and phenotypic/epigenetic changes resulting in modification of cancer cell 
properties. CTCs are in that context an easy accessible biological material and an unavoidable tool in the functional study of tumor progression. However, the lack of standardized procedures for the isolation and characterization of CTCs restricts current CTC investigations to research. A combination of CTC isolation with full genomic and downstream RNA analyses is a promising approach to better reflect the therapeutic response, to anticipate drug resistance and to adapt treatment day by day, patient per patient [47]. A kinetic profile of CTCs compared to tumor tissue will complete the full picture of the disease progression and may be the basis of the future personalized medicine in oncology.

Acknowledgments: This study was written as a part of a research project which was funded by the Bone Cancer Research Trust (UK, research project number 144681). 


\section{References}

[1]. Marusyk A, Almendro V, Polyak K. Intra-tumour heterogeneity: a looking glass for cancer? Nat Rev Cancer 2012;12:323-34.

[2]. Paget S. The distribution of secondary growths in cancer of the breast. 1889 . Cancer Metastasis Rev 1989;8:98-101.

[3]. Pienta KJ, McGregor N, Axelrod R, Axelrod DE. Ecological therapy for cancer: defining tumors using an ecosystem paradigm suggests new opportunities for novel cancer treatments. Transl Oncol 2008;1:158-64.

[4]. Barber LJ, Davies MN, Gerlinger M. Dissecting cancer evolution at the macroheterogeneity and micro-heterogeneity scale. Curr Opin Genet Dev 2015;30:16.

[5]. Merlo LM, Pepper JW, Reid BJ, Maley CC. Cancer as an evolutionary and ecological process. Nat Rev Cancer 2006; 6: 924-35.

[6]. Nowell PC. The clonal evolution of tumor cell populations. Science 1976; 194 : 23-8.

[7]. Gay L, Baker AM, Graham TA. Tumour Cell Heterogeneity. F1000Research 2016; 5:238.

[8]. Gundem G, Van Loo P, Kremeyer B, Alexandrov LB, Tubio JM, Papaemmanuil E, Brewer DS, Kallio HM, Högnäs G, Annala M, Kivinummi K, Goody V, Latimer C, O'Meara S, Dawson KJ, Isaacs W, Emmert-Buck MR, Nykter M, Foster C, Kote-Jarai Z, Easton D, Whitaker HC, ICGC Prostate UK Group, Neal DE, Cooper CS, Eeles RA, Visakorpi T, Campbell PJ, McDermott U, Wedge DC, Bova GS, University of Washington-Urology, Seattle, WA. The evolutionary history of lethal metastatic prostate cancer. Nature 2015; 520:353-57.

[9]. Mazor T, et al. Intratumoral Heterogeneity of the Epigenome. Cancer cell 2016; 29:440-51.

[10]. Varela I, Menendez P, Sanjuan-Pla A. Intratumoral heterogeneity and clonal evolution in blood malignancies and solid tumors. Oncotarget 2017;8:66742-746.

[11]. Reymond N, d'Água BB, Ridley AJ. Crossing the endothelial barrier during metastasis. Nat Rev Cancer $2013 ; 13: 858-70$.

[12]. Chambers AF, Groom AC, MacDonald IC. Dissemination and growth of cancer 
cells in metastatic sites. Nat Rev Cancer 2002 ; 2:563-72.

[13]. Ortiz V, Yu M. Analyzing circulating tumor cells one at a time. Trends Cell Biol 2018 (in press) doi: 10.1016/j.tcb.2018.05.004.

[14]._Allison KH, Sledge GW. Heterogeneity and cancer. Oncology (Williston Park) 2014;28:772-8.

[15]. Dawson SJ. Characterizing the cancer genome in blood. Cold Spring Harb Perspect Med. 2018 (in press) doi: 10.1101/cshperspect.a026880

[16]. Ramalingam N, Jeffrey SS. Future of liquid biopsies with growing technological and bioinformatics studies: opportunities and challenges in discovering tumor heterogeneity with single-cell level analysis. Cancer J 2018;24:104-108.

[17]. Aceto N, Bardia A, Miyamoto DT, Donaldson MC, Wittner BS, Spencer JA, Yu M, Pely A, Engstrom A, Zhu H, Brannigan BW, Kapur R, Stott SL5, Shioda T, Ramaswamy S1, Ting DT, Lin CP, Toner M, Haber DA, Maheswaran S. Circulating tumor cell clusters are oligoclonal precursors of breast cancer metastasis. Cell $2014 ; 158: 1110-122$.

[18]. Au SH, Storey BD, Moore JC, Tang Q, Chen YL, Javaid S, Sarioglu AF, Sullivan R, Madden MW, O'Keefe R, Haber DA, Maheswaran S, Langenau DM, Stott SL, Toner M. Clusters of circulating tumor cells traverse capillarysized vessels. Proc Natl Acad Sci U S A 2016;113:4947-52.

[19]. Sawabata N. Circulating tumor cells in lung cancer: cluster circulating tumor cells as hybrid epithelial-mesenchymal transition/mesenchymal-epithelial transition (E/M). J Thorac Dis 2017;9:3547-550.

[20]. Sharma S, Zhuang R, Long M, Pavlovic M, Kang Y, Iliyas A, Asghar W. Circulating tumor cell isolation, culture, and downstream molecular analysis. Biotechnol Adv 2018;36:1063-78.

[21]. Alix-Panabières C, Pantel K. Challenges in circulating tumour cell research. Nat Rev Cancer 2014 ;14:623-31.

[22]. Krebs MG, Metcalf RL, Carter L, Brady G, Blackhall FH, Dive C. Molecular analysis of circulating tumour cells-biology and biomarkers. Nat Rev Clin Oncol $2014 ; 11: 129-44$.

[23]. Gabriel MT, Calleja LR, Chalopin A, Ory B, Heymann D. Circulating tumor cells: a review of non-EpCAM-based approaches for cell enrichment and isolation. Clin Chem 2016;62:571-81

[24]. Tellez-Gabriel M, Ory B, Lamoureux F, Heymann MF, Heymann D. Tumour Heterogeneity: The key Advantages of single-cell analysis. Int $\mathrm{J}$ Mol Sci 2016;17(12). 
[25]. Gertler R, Rosenberg R, Fuehrer K, Dahm M, Nekarda H, Siewert JR. Detection of circulating tumor cells in blood using an optimized density gradient centrifugation. Recent Results Cancer Res 2003;162 :149-55.

[26]. Khetani S, Mohammadi M, Nezhad AS. Filter-based isolation, enrichment and characterization of circulating tumor cells. Biotechnol Bioeng 2018 (in press). doi: 10.1002/bit.26787.

[27]. Desitter I, Guerrouahen BS, Benali-Furet N, Wechsler J, Jänne PA, Kuang Y, et al. A new device for rapid isolation by size and characterization of rare circulating tumor cells. Anticancer Res 2011;31:427-41.

[28]. Freidin MB, Tay A, Freydina DV, Chudasama D, Nicholson AG, Rice A, et al. An assessment of diagnostic performance of a filter-based antibody-independent peripheral blood circulating tumour cell capture paired with cytomorphologic criteria for the diagnosis of cancer. Lung Cancer 2014;85:182-85.

[29]. Tan SJ, Yobas L, Lee GY, Ong CN, Lim CT. Microdevice for the isolation and enumeration of cancer cells from blood. Biomed Microdevices 2009;11:88392.

[30]. Becker FF, Wang XB, Huang Y, Pethig R, Vykoukal J, Gascoyne P. Separation of human breast cancer cells from blood by differential dielectric affinity. Proc Natl Acad Sci U S A 1995;92:860-4.

[31]. Chalopin A, Tellez-Gabriel M, Brown HK, Vallette F, Heymann MF, Gouin F, Heymann D. Isolation of circulating tumor cells in a preclinical model of osteosarcoma: effect of chemotherapy. J Bone Oncol 2018 (in press). doi: 10.1016/j.jbo.2018.07.002

[32]. Bolognesi C, Doffini A, Busson G, Lanzellotto, Signorini G, Sero V Lanzellotto R, Signorini G, Calanca A, Sergio M, Romano R, Gianni S, Medoro G, Giorgini G, Morreau H, Barberis M, Corver WE, Manaresi N. Digital sorting of pure cell populations enables unambiguous genetic analysis of heterogeneous formalin-fixed paraffin-embedded tumors by next generation sequencing. Sci Rep 2016;6:20944.

[33]. Wu M, Huang PH, Zhang R, Mao Z, Chen C, Kemeny G, Li P, Lee AV, Gyanchandani R, Armstrong AJ, Dao M, Suresh S, Huang TJ. Circulating tumor cell phenotyping via high-throughput acoustic separation. Small 2018 (in press). doi: 10.1002/smll.201801131

[34]. Andreopoulou E, Yang LY, Rangel KM, Reuben JM, Hsu L, Krishnamurthy S, Valero V, Fritsche HA, Cristofanilli M. Comparison of assay methods for detection of circulating tumor cells in metastatic breast cancer: AdnaGen AdnaTest breast cancer select/detect versus Veridex CellSearch system. Int J Cancer 2011;130:1590-7. 
[35]. Ramirez JM, Fehm T, Orsini M, Cayrefourcq L, Maudelonde T, Pantel K, AlixPanabières C. Prognostic relevance of viable circulating tumor cells detected by EPISPOT in metastatic breast cancer patients. Clin Chem 2014;60:214-21.

[36]. Alix-Panabières C, Mader S, Pantel K. Epithelial-mesenchymal plasticity in circulating tumor cells. J Mol Med 2017;95:133-42

[37]. Jordan NV, Bardia A, Wittner BS, Benes C, Ligorio M, Zheng Y, Yu M, Sundaresan TK, Licausi JA, Desai R, O'Keefe RM, Ebright RY, Boukhali M, Sil S, Onozato ML, Iafrate AJ, Kapur R, Sgroi D, Ting DT, Toner M, Ramaswamy S, Haas W, Maheswaran S, Haber DA. HER2 expression identifies dynamic functional states within circulating breast cancer cells. Nature 2016;537:102-6.

[38]. Bidard FC, Michiels S, Riethdorf S, Mueller V, Esserman LJ, Lucci A, Naume B, Horiguchi J, Gisbert-Criado R, Sleijfer S, Toi M, Garcia-Saenz JA, Hartkopf A, Generali D, Rothé F, Smerage J, Muinelo-Romay L, Stebbing J, Viens P, Magbanua MJM, Hall CS, Engebraaten O, Takata D, Vidal-Martínez J, Onstenk W, Fujisawa N, Diaz-Rubio E, Taran FA, Cappelletti MR, Ignatiadis M, Proudhon C, Wolf DM, Bauldry JB, Borgen E, Nagaoka R, Carañana V, Kraan J, Maestro M, Brucker SY, Weber K, Reyal F, Amara D, Karhade MG, Mathiesen RR, Tokiniwa H, Llombart-Cussac A, Meddis A, Blanche P, d'Hollander K, Pantel K. Circulating tumor cells in breast cancer patients treated by neoadjuvant chemotherapy: a meta-analysis. J Natl Cancer Inst 2018; (in press)

[39]. Kaigorodova EV, Savelieva OE, Tashireva LA, Tarabanovskaya NA, Simolina EI, Denisov EV, Slonimskaya EM, Choynzonov EL, Perelmuter VM. Heterogeneity of circulating tumor cells in neoadjuvant chemotherapy of breast cancer. Molecules 2018;23.

[40]. Jakabova A, Bielcikova Z, Pospisilova E, Matkowski R, Szynglarewicz B, Staszek-Szewczyk U, Zemanova M, Petruzelka L, Eliasova P, Kolostova K, Bobek V. Molecular characterization and heterogeneity of circulating tumor cells in breast cancer. Breast Cancer Res Treat 2017;166:695-700.

[41]. Bingham C, Fernandez SV, Fittipaldi P, Dempsey PW, Ruth KJ, Cristofanilli M, Katherine Alpaugh R. Mutational studies on single circulating tumor cells isolated from the blood of inflammatory breast cancer patients. Breast Cancer Res Treat 2017;163:219-30.

[42]. Aaltonen KE, Novosadová V, Bendahl PO, Graffman C, Larsson AM, Rydén L. Molecular characterization of circulating tumor cells from patients with metastatic breast cancer reflects evolutionary changes in gene expression under the pressure of systemic therapy. Oncotarget 2017;8:45544-565.

[43]. Gasch C, Oldopp T, Mauermann O, Gorges TM, Andreas A, Coith C, Müller V, Fehm T, Janni W, Pantel K, Riethdorf S. Frequent detection of PIK3CA mutations in single circulating tumor cells of patients suffering from HER2negative metastatic breast cancer. Mol Oncol 2016;10:1330-43. 
[44]. Scher HI, Graf RP, Schreiber NA, McLaughlin B, Jendrisak A, Wang Y, Lee J, Greene S, Krupa R, Lu D, Bamford P, Louw JE, Dugan L, Vargas HA, Fleisher M, Landers M, Heller G, Dittamore R. Phenotypic heterogeneity of circulating tumor cells informs clinical decisions between AR signaling inhibitors and taxanes in metastatic prostate cancer. Cancer Res 2017;77:568798.

[45]. Lack J, Gillard M, Cam M, Paner GP, VanderWeele DJ. Circulating tumor cells capture disease evolution in advanced prostate cancer. J Transl Med 2017;15:44.

[46]. Kermanshah L, Poudineh M, Ahmed S , Nguyen LNM, Srikant S, Makonnen R, Pena Cantu F , Corrigan M , Kelley SO . Dynamic CTC phenotypes in metastatic prostate cancer models visualized using magnetic ranking cytometry. Lab Chip 2018;18:2055-64.

[47]. Markou A, Lazaridou M, Paraskevopoulos P, Chen S, Świerczewska M, Budna J, Kuske A, Gorges TM, Joosse SA, Kroneis T, Zabel M, Sedlmayr P, AlixPanabières C, Pantel K, Lianidou ES. Multiplex gene expression profiling of in vivo isolated circulating tumor cells in high-risk prostate cancer patients. Clin Chem 2018;64:297-306.

[48]. Sun YF, Guo W, Xu Y, Shi YH, Gong ZJ, Ji Y, Du M, Zhang X, Hu B, Huang A, Chen GG, Lai PBS, Cao Y, Qiu SJ, Zhou J, Yang XR, Fan J. Circulating tumor cells from different vascular sites exhibit spatial heterogeneity in epithelial and mesenchymal composition and distinct cinical significance in hepatocellular carcinoma. Clin Cancer Res 2018;24:547-59.

[49]. Kondo Y, Hayashi K, Kawakami K, Miwa Y, Hayashi H, Yamamoto M. KRAS mutation analysis of single circulating tumor cells from patients with metastatic colorectal cancer. BMC Cancer 2017;17:311.

[50]. Tan K, Leong SM, Kee Z, Caramat PV, Teo J, Blanco MVM, Koay ESC, Cheong WK, Soh TI, Yong WP, Pang A. Longitudinal monitoring reveals dynamic changes in circulating tumor cells (CTCs) and CTC-associated miRNAs in response to chemotherapy in metastatic colorectal cancer patients. Cancer Lett 2018;423:1-8.

[51]. Messaritakis I, Stoltidis D, Kotsakis A, Dermitzaki EK, Koinis F, Lagoudaki E, Koutsopoulos A, Politaki E, Apostolaki S, Souglakos J, Georgoulias V. TTF1- and/or CD56-positive circulating tumor cells in patients with small cell lung cancer (SCLC). Sci Rep 2017;7:45351.

[51]. Paoletti C, Cani AK, Larios JM, Hovelson DH, Aung K, Darga EP, Cannell EM, Baratta PJ, Liu CJ, Chu D, Yazdani M, Blevins AR, Sero V, Tokudome N, Thomas DG, Gersch C, Schott AF, Wu YM, Lonigro R, Robinson DR, Chinnaiyan AM, Bischoff FZ, Johnson MD, Park BH, Hayes DF, Rae JM, 
Tomlins SA. comprehensive mutation and copy number profiling in archived circulating breast cancer tumor cells documents heterogeneous resistance mechanisms. Cancer Res 2018;78:1110-22.

[52]. De Luca F, Rotunno G, Salvianti F, Galardi F, Pestrin M, Gabellini S, Simi L, Mancini I, Vannucchi AM, Pazzagli M, Di Leo A, Pinzani P. Mutational analysis of single circulating tumor cells by next generation sequencing in metastatic breast cancer. Oncotarget 2016;7:26107-19.

[53]. Jiang R, Lu YT, Ho H, Li B, Chen JF, Lin M, Li F, Wu K, Wu H, Lichterman J, Wan H, Lu CL, OuYang W, Ni M, Wang L, Li G, Lee T, Zhang X, Yang J, Rettig M, Chung LW, Yang H, Li KC, Hou Y, Tseng HR, Hou S, Xu X, Wang J, Posadas EM. A comparison of isolated circulating tumor cells and tissue biopsies using whole-genome sequencing in prostate cancer. Oncotarget $2015 ; 6: 44781-93$.

[54]. Carlsson A, Kuhn P, Luttgen MS, Dizon KK, Troncoso P, Corn PG, Kolatkar A, Hicks JB, Logothetis CJ, Zurita AJ. Paired High-Content Analysis of Prostate Cancer Cells in Bone Marrow and Blood Characterizes Increased Androgen Receptor Expression in Tumor Cell Clusters. Clin Cancer Res 2017;23:1722-1732.

[55]. Lyberopoulou A, Aravantinos G, Efstathopoulos EP, Nikiteas N, Bouziotis P, Isaakidou A, Papalois A, Marinos E, Gazouli M. Mutational analysis of circulating tumor cells from colorectal cancer patients and correlation with primary tumor tissue. PLoS One 2015;10:e0123902.

[56]. Liu Y, Meucci S, Sheng L, Keilholz U. Meta-analysis of the mutational status of circulation tumor cells and paired primary tumor tissues from colorectal cancer patients. Oncotarget 2017;8:77928-941.

[57]. Guibert N, Delaunay M, Lusque A, Boubekeur N, Rouquette I, Clermont E, Mourlanette J, Gouin S, Dormoy I, Favre G, Mazieres J, Pradines A. PD-L1 expression in circulating tumor cells of advanced non-small cell lung cancer patients treated with nivolumab. Lung Cancer 2018;120:108-12.

[58]. Kermanshah L, Poudineh M, Ahmed S, Nguyen LNM, Srikant S , Makonnen R, Pena Cantu F , Corrigan M, Kelley SO . Dynamic CTC phenotypes in metastatic prostate cancer models visualized using magnetic ranking cytometry. Lab Chip 2018;18:2055-64.

[59]. Lack J, Gillard M, Cam M, Paner GP, VanderWeele DJ. Circulating tumor cells capture disease evolution in advanced prostate cancer. J Transl Med 2017;15:44.

[60]. Khoo BL, Grenci G, Lim YB, Lee SC, Han J, Lim CT. Expansion of patientderived circulating tumor cells from liquid biopsies using a CTC microfluidic culture device. Nat Protoc 2018;13:34-58. 


\section{Figure legend}

Figure 1 : Origin of tumor heterogeneity. All components of a tumor mass are affected by heterogeneity. (A) Tumor tissues are composed of diverse cancer cells exhibiting innate resistance to specific drugs which is prone to be amplified during the course of treatment. In addition, under drug pressure, cancer cells can acquire molecular mechanisms to form resistant clones de novo. (B) Tumor evolution associates clonal proliferation, genetic instability with random mutational changes, and epigenetic modifications within the clonal population resulting in genetic diversity. The tumor microenvironment is a key regulator of these processes. (C) Tumor heterogeneity is amplified by cell reseeding of cancer cells from one site (primary or metastatic) to another site (primary or metastatic). In addition to this autoamplification, epigenetic events strongly increase the cell diversity and strengthen the heterogeneity of cancer cells.

Figure 2: Isolation methods of circulating tumor cells (CTCs). Numerous technical approaches have been developed for CTC isolation. These methods are based on the biological characteristics and physical properties of CTCs. CTCs usually require a pre-enrichment step of the biological fluids before their isolation. There is no perfect method, all of them have advantages and limitations and the choice of the tool used depends on the main objective of the study. The table presented is not an exhaustive list of devices available but the list of the main techniques currently used. 


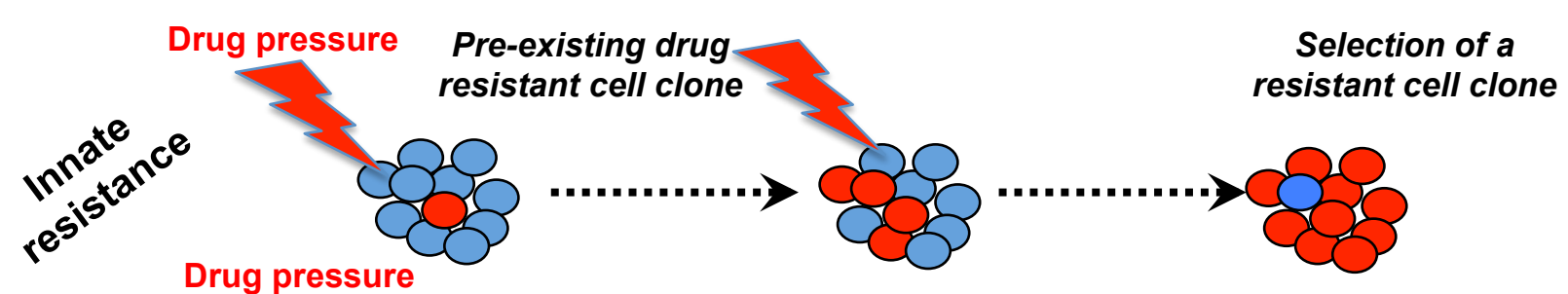

Drug pressure

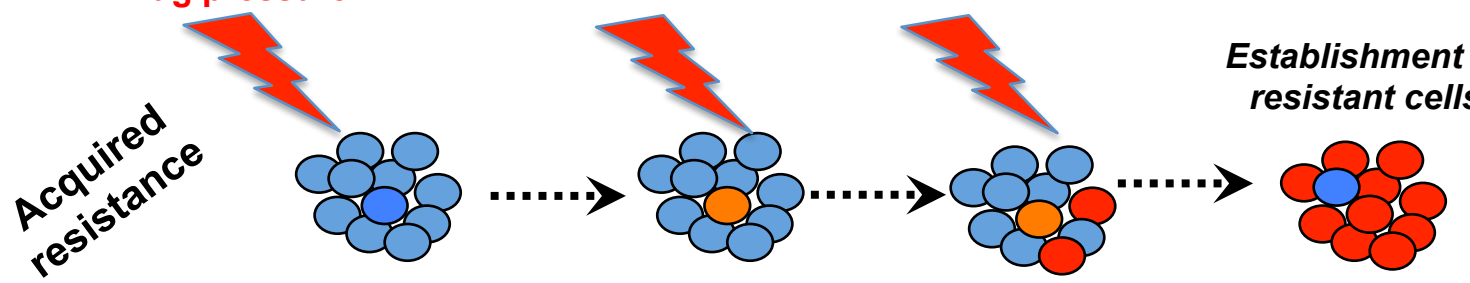

B
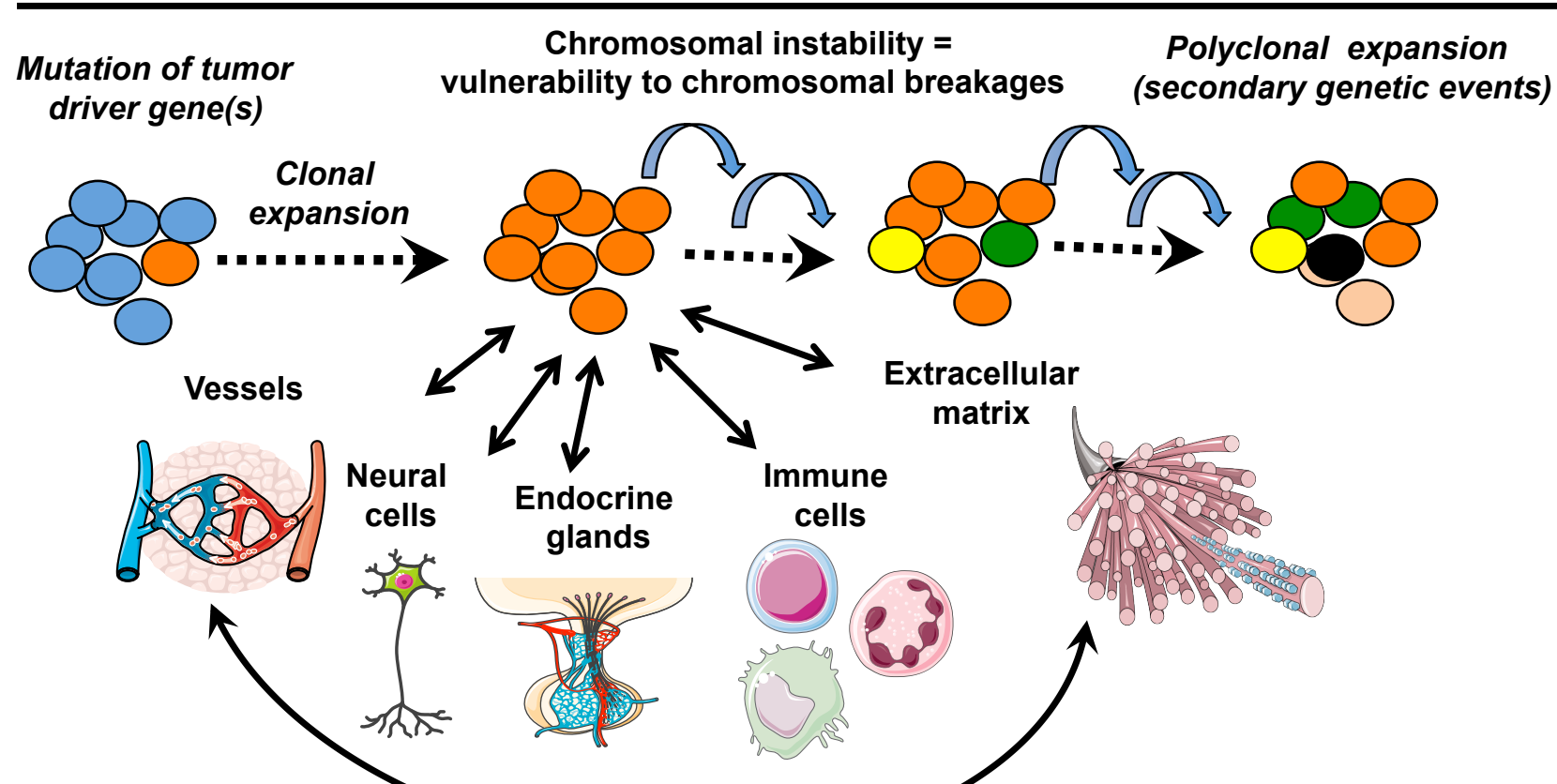

C

Pressure of the microenvironment

Extracellular matrix
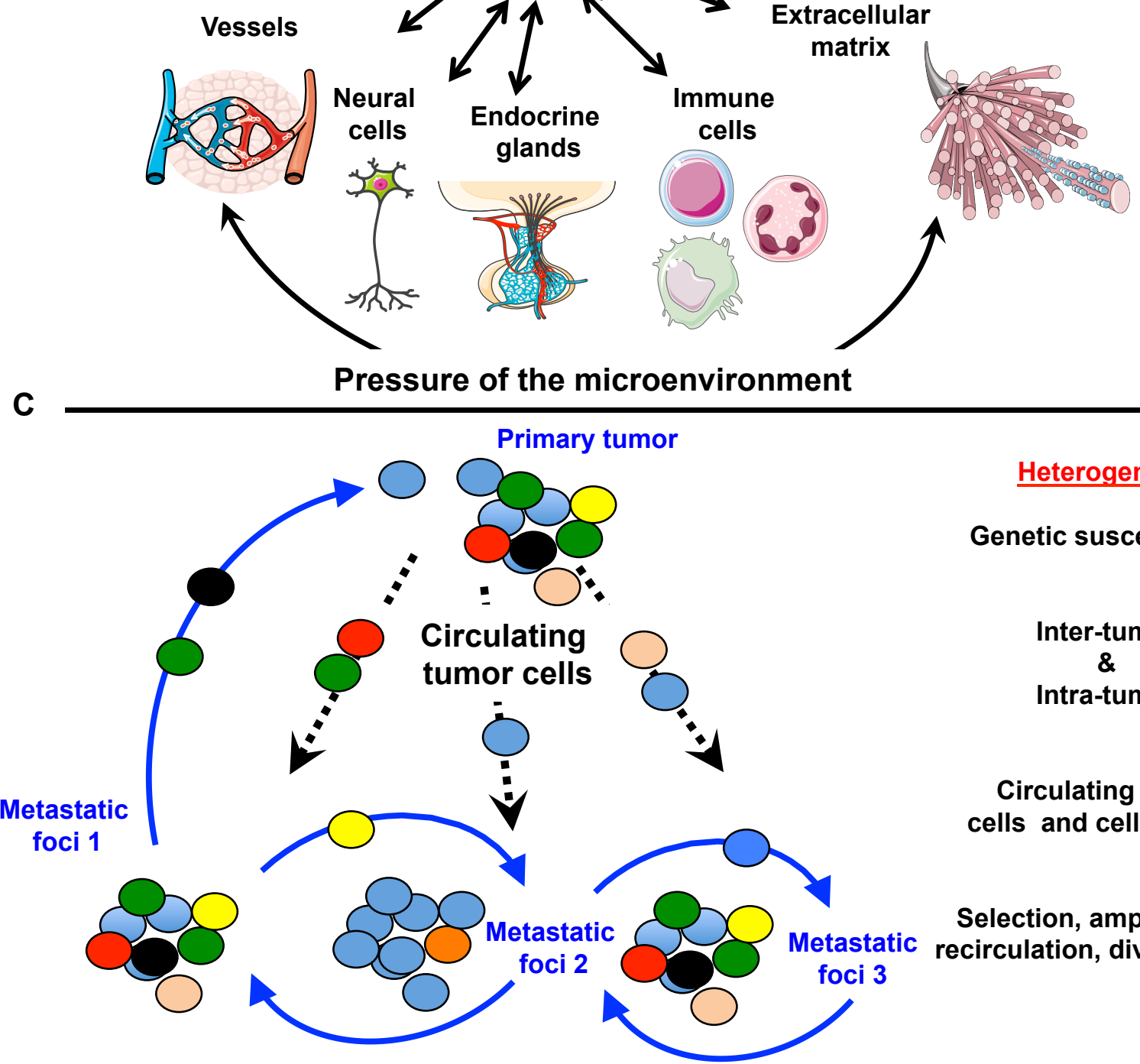

Primary tumor

Disseminating tumor cells

\section{Heterogeneity}

Genetic susceptibility

Inter-tumor

$\&$

Intra-tumor

Circulating tumor cells and cell clusters

Selection, amplification, recirculation, diversification 
Figure 2

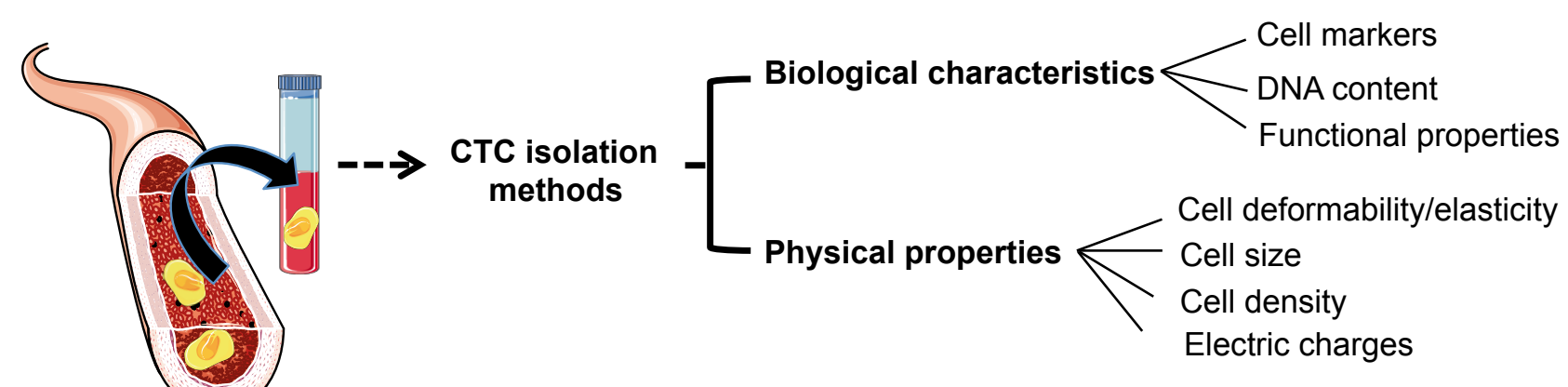


Table 1: Main techniques currently used for isolating circulating tumor cells

\begin{tabular}{|c|c|c|c|}
\hline \multicolumn{4}{|c|}{ Methods based on physical properties } \\
\hline Technology & Name & Advantages & Limitations \\
\hline Density gradient & $\begin{array}{l}\text { Percoll } \\
\text { Ficoll-HyPaque } \\
\text { OncoQuick }\end{array}$ & $\begin{array}{l}\text { - Low cost } \\
\text { - Reliable }\end{array}$ & $\begin{array}{l}\text { - Low purity (should be } \\
\text { considered as a pre-enrichment } \\
\text { step) } \\
\text { - Risk to lose large CTCs and } \\
\text { CTC clusters }\end{array}$ \\
\hline Microfiltration & $\begin{array}{l}\text { ScreenCell } \\
\text { ISET (isolation by size of epithelial tumor cells) } \\
\text { CellCyto }\end{array}$ & $\begin{array}{l}\text { - Relative high speed process } \\
\text { - Biomarker independent } \\
\text { - High efficiency }\end{array}$ & $\begin{array}{l}\text { - Low purity } \\
\text { - Risk to lose small CTCs } \\
\text { (diameter lower than white blood } \\
\text { cells) } \\
\text { - ISET: CTC can be damaged or } \\
\text { fragmented }\end{array}$ \\
\hline $\begin{array}{l}\text { Microfluidic technics } \\
\text { (including microfluidic } \\
\text { adhesion-based devices) }\end{array}$ & $\begin{array}{l}\text { ApoStream } \\
\text { ClearCell FX } \\
\text { Cluster CTC-Chip } \\
\text { CTC-iChip } \\
\text { Dielectrophoresis (DEP) : DEPArray } \\
\text { Ephesia CTC-Chip } \\
\text { OncoCEE (cell enrichment and extraction) } \\
\text { OnQChip } \\
\text { Parsortix }\end{array}$ & $\begin{array}{l}\text { - Cell viability } \\
\text { - Efficiency } \\
\text { - Single cell isolation } \\
\text { - High sensitivity } \\
\text { - DEPArray: possibility to } \\
\text { evaluate the DNA content }\end{array}$ & $\begin{array}{l}\text { - Relatively expensive } \\
\text { - Time consuming approach } \\
\text { - Pre-enrichment step required for } \\
\text { reducing the initial volume } \\
\text { - Biomarker dependent } \\
\text { - DEPArray: required specific } \\
\text { electric properties } \\
\text { - CTC-iChip: limited to small } \\
\text { clusters composed up to } 4 \text { cells }\end{array}$ \\
\hline \multicolumn{4}{|c|}{ Methods based on biological characteristics } \\
\hline $\begin{array}{l}\text { Antibody-conjugated } \\
\text { magnetic nanoparticles } \\
\text { or microbeads or } \\
\text { functionalized cell } \\
\text { collectors }\end{array}$ & $\begin{array}{l}\text { AdnaTest } \\
\text { CellSearch } \\
\text { Dynabeads } \\
\text { EasySep } \\
\text { IsoFlux } \\
\text { MACS } \\
\text { MagniSort } \\
\text { MagSweper } \\
\text { MojorSort } \\
\text { RosetteSep } \\
\text { Gilupi CellCollector }\end{array}$ & $\begin{array}{l}\text { - Cell viability } \\
\text { - High efficiency } \\
\text { - High purity } \\
\text { - CellSearch: the only FDA- } \\
\text { approved system for the use in } \\
\text { diagnostic (metastatic breast, } \\
\text { prostate and colorectal } \\
\text { cancers) }\end{array}$ & - Biomarker dependent \\
\hline Functional properties & $\begin{array}{l}\text { EPISPOT } \\
\text { CAM (Chick chorioallantoic membrane) assay } \\
\text { Telomerase activity (TelomeScan) }\end{array}$ & - High sensitivity and specifity & $\begin{array}{l}\text { - EPISPOT: Requires efficient } \\
\text { antigen binding and specific } \\
\text { epitope presentation }\end{array}$ \\
\hline
\end{tabular}


Table 2. Non-exhaustive list of ongoing clinical trials based on the detection of circulating tumor cells (total recruiting studies: 79)

\begin{tabular}{|c|c|c|c|c|c|}
\hline Reference & Title & Organs (+ treatment) & Outcome & Patients & $\begin{array}{c}\text { Study } \\
\text { completion }\end{array}$ \\
\hline NCT01619111 & $\begin{array}{l}\text { DETECT III - A multicenter, phase } \\
\text { III study to compare standard } \\
\text { therapy +/- laptinib in HER2-ve } \\
\text { MBC-patients with HER2+ve CTCs }\end{array}$ & Breast cancer & $\begin{array}{l}\text { - CTC clearance rate } \\
\text { - Overall response rate } \\
\text { - Clinical benefit rate } \\
\text { - Overall survival } \\
\text { - Dynamic of CTC } \\
\text { - Safety and tolerability of lapatinib } \\
\text { - Progression free survival }\end{array}$ & 120 & 2020 \\
\hline NCT02035813 & $\begin{array}{l}\text { DETECT IV - A study in patients } \\
\text { with Her2-negative metastatic } \\
\text { breast cancer and persisting Her- } \\
\text { negative CTCs }\end{array}$ & $\begin{array}{l}\text { Breast cancers (Everolimus, } \\
\text { Eribulin) }\end{array}$ & $\begin{array}{l}\text { - Progression-free survival and over-all survival } \\
\text { - Overall response rate } \\
\text { - Dynamic of CTCs } \\
\text { - Quantification of CTC (for everolimus: levels of pS6, } \\
\text { change in the activation of the PI3K/Akt/mTOR pathway; } \\
\text { ESR1 mutation; for eribulin: new metastasis-free survival) }\end{array}$ & 520 & 2019 \\
\hline NCT03070002 & $\begin{array}{l}\text { Denosumab in treating patients with } \\
\text { ER and/or PR positive HER2 } \\
\text { negative metastatic breast cancer } \\
\text { with bone metastases and } \\
\text { detectable CTCs }\end{array}$ & Breast cancer (Denosumab) & $\begin{array}{l}\text { - Fraction of patients with reduction in CTCs } \\
\text { - Percent changes in CTCs } \\
\text { - Progression free survival }\end{array}$ & 42 & 2019 \\
\hline NCT01322750 & $\begin{array}{l}\text { CTCs: a potential screening test for } \\
\text { clinically } \begin{array}{l}\text { undetectable } \\
\text { carcinoma }\end{array}\end{array}$ & Breast cancer & - Observational study & 3125 & 2023 \\
\hline NCT01961713 & $\begin{array}{l}\text { CTC analysis in patients with } \\
\text { localized prostate cancer } \\
\text { undergoing prostatectomy }\end{array}$ & Prostate cancer & $\begin{array}{l}\text { - Relationship CTC quantity and pathologic stage } \\
\text { - Persistent CTC and biochemical recurrence } \\
\text { - Compare chromosome translocation status }\end{array}$ & 200 & 2019 \\
\hline NT02997709 & $\begin{array}{l}\text { Collection and measurement of } \\
\text { biomarkers in prostate cancer } \\
\text { radiotherapy patients }\end{array}$ & Prostate cancer & $\begin{array}{l}\text { - Relationship CTC changes and/or quantitative imaging } \\
\text { parameter changes to patient outcome } \\
\text { - Comparison of changes in CTCs to endpoint prostate } \\
\text { research biopsy status }\end{array}$ & 300 & 2026 \\
\hline NCT03327662 & $\begin{array}{l}\text { Utilising CTC counts to optimize } \\
\text { systemic therapy of metastatic } \\
\text { prostate cancer }\end{array}$ & Prostate cancer & $\begin{array}{l}\text { - Overall survival } \\
\text { - CTC-guided switch rates } \\
\text { - CTC effects in chemotherapy }\end{array}$ & 1178 & 2022 \\
\hline NCT01558349 & $\begin{array}{l}\text { CTCs as biomarker for prostate } \\
\text { cancer detection in patients with } \\
\text { gray zone PSA level }\end{array}$ & Prostate cancer & - CTC detection & 500 & 2021 \\
\hline NCT02456571 & CTC immune checkpoint & prostate cancer & $\begin{array}{l}\text { - Change in expression of four immune checkpoint } \\
\text { biomarkers (PD-L1, PD-L2, B7-H3 and CTLA-4- on CTCs }\end{array}$ & 40 & 2019 \\
\hline
\end{tabular}




\begin{tabular}{|c|c|c|c|c|c|}
\hline NCT02449837 & $\begin{array}{l}\text { Investigation of CTCs from cancer } \\
\text { patients undergoing radiation } \\
\text { therapy }\end{array}$ & $\begin{array}{l}\text { Non metastatic disease: } \\
\text { Head and Neck cancer; } \\
\text { Cervical cancer; Non-small } \\
\text { cell lung cancer; Rectal } \\
\text { cancer; Metastatic prostate } \\
\text { cancer } \\
\text { Oligometastatic disease }\end{array}$ & $\begin{array}{l}\text { - CTC levels during the treatment comparing metastatic } \\
\text { and non metastastic disease }\end{array}$ & 210 & 2020 \\
\hline NCT03295591 & CTCs in mCRC for liver resection & Metastatic colo-rectal cancer & $\begin{array}{l}\text { - Cutoff value of CTC counts [time frame: Progression free } \\
\text { survival at } 6 \text { months] } \\
\text { - to identify patients with early relapse ( }<6 \text { months) after } \\
\text { liver resection }\end{array}$ & 77 & 2020 \\
\hline NCT03156777 & $\begin{array}{l}\text { Application value of CTCs detection } \\
\text { for advanced gastric cancer patients }\end{array}$ & Gastric cancer & $\begin{array}{l}\text { - Number of CTCs } \\
\text { - Profile of CTCs } \\
\text { - Progression free survival and overall survival }\end{array}$ & 200 & 2020 \\
\hline NCT02955173 & $\begin{array}{l}\text { Significance of CTCs in the } \\
\text { treatment of gastric and rectal } \\
\text { cancer }\end{array}$ & Gastric and colorectal cancer & $\begin{array}{l}\text { - Disease-free survival } \\
\text { - CTC test }\end{array}$ & 600 & 2019 \\
\hline NCT02874885 & CTCs in patients with rectal cancer & Rectal cancer & - Changes in CTC status & 520 & 2023 \\
\hline NCT02335151 & CTC pancreatic adenocarcinoma & Pancreatic cancer & $\begin{array}{l}\text { - Peak of CTCs in the postoperative phase after curative } \\
\text { tumor removal, kinetic of CTCs up to day } 7 \\
\text { - Months to tumor recurrence and number of surviving } \\
\text { patients }\end{array}$ & 56 & 2019 \\
\hline NCT02072616 & $\begin{array}{l}\text { Detection of CTCs for the diagnosis } \\
\text { of pancreatic adenocarcinoma }\end{array}$ & Pancreatic cancer & $\begin{array}{l}\text { - Sensitivity of CTCs for the diagnosis } \\
\text { - Performance of ctDNA (KRAS) for the diagnosis } \\
\text { - Prognostic impact of CTC/ctDNA (KRAS) and/or CA19.9 } \\
\text { - Time to first recurrence or death }\end{array}$ & 142 & 2021 \\
\hline NCT03340844 & $\begin{array}{l}\text { Role of CTC's spread during } \\
\text { pancreaticoduodenecomy in } \\
\text { patients with pancreatic and } \\
\text { periampullary tumors }\end{array}$ & Pancreatic cancer & $\begin{array}{l}\text { - CTC detecion } \\
\text { - Local tumor recurrence } \\
\text { - Metastasis } \\
\text { - Patient survival }\end{array}$ & 62 & 2022 \\
\hline NCT03295591 & CTC in mCRC for liver resection & Liver cancer & $\begin{array}{l}\text { - Cutoff value of CTC counts } \\
\text { - Progession free survival and overall survival }\end{array}$ & 77 & 2020 \\
\hline NCT02973204 & $\begin{array}{l}\text { CTC and tumor DNA in HCC and } \\
\text { NET }\end{array}$ & $\begin{array}{l}\text { Hepatocellular carcinoma } \\
\text { Neuroendocrine tumors }\end{array}$ & $\begin{array}{l}\text { - Flow cytometry for detection of CTC in peripheral blood } \\
\text { (absolute and relative count) } \\
\text { - Correlation between mutations found in ctDNA and CTC } \\
\text { and survival/treatment response according to RECIST } \\
\text { criteria }\end{array}$ & 130 & 2020 \\
\hline NCT02812680 & $\begin{array}{l}\text { The utility of CTCs and plasma } \\
\text { microRNA in } \\
\text { adenocarcinoma }\end{array}$ & Esophageal cancer & $\begin{array}{l}\text { - CTCs and miRNA as biomarkers of cancer and predictive } \\
\text { markers for neoadjuvant therapy by using CTCs chips }\end{array}$ & 100 & 219 \\
\hline
\end{tabular}




\begin{tabular}{|c|c|c|c|c|c|}
\hline NCT02951897 & $\begin{array}{l}\text { Application of detecting CTCs in the } \\
\text { accurate treatment of early stage } \\
\text { lung adenocarinoma }\end{array}$ & Lung Cancer & - Disease free survival & 120 & 2019 \\
\hline NCT02630615 & CTCs in lung cancer & Lung cancer & $\begin{array}{l}\text { - Assess activity of novel DNA repair inhibitors as a } \\
\text { function of DNA repair mutations detected in CTC samples }\end{array}$ & 80 & 2020 \\
\hline NCT03479099 & Liquid biopsy in lung cancer & Lung cancer & $\begin{array}{l}\text { - Diagnostic sensitivity/accuracy/specificity of combined } \\
\text { CTC and ctDNA }\end{array}$ & 130 & 2019 \\
\hline NCT02499458 & $\begin{array}{l}\text { Prospective validation of CTC and } \\
\text { Circulating endothelial cells as } \\
\text { biomarkers in renal cancer }\end{array}$ & Renal cancer & $\begin{array}{l}\text { - Sensitivity/specificity of CTC enumeration (microfluidics } \\
\text { vs CellSearch) } \\
\text { - Progression free survival } \\
\text { - Overall survival } \\
\text { - Molecular characterization of CTCs }\end{array}$ & 70 & 2019 \\
\hline \multirow[t]{2}{*}{ NCT02246738 } & $\begin{array}{l}\text { Initial evaluation of a telomerase- } \\
\text { based CTC assay in bladder cancer } \\
\text { cohorts }\end{array}$ & Bladder cancer & - Number of adverse events & 66 & 2018 \\
\hline & $\begin{array}{l}\text { Detection of CTC in patients with } \\
\text { sarcomas }\end{array}$ & Sarcoma & - Progression free survival & 20 & 2018 \\
\hline
\end{tabular}

Source : clinical trials.gov 